\title{
Correction to: A note on dual prehomomorphisms from a group into the Margolis-Meakin expansion of a group
}

\author{
Bernd Billhardt ${ }^{1} \cdot$ Boorapa Singha $^{2} \cdot$ Worachead Sommanee $^{2}$. \\ Paweena Thamkaew ${ }^{2} \cdot$ Jukrapong Tiammee ${ }^{2}$
}

Published online: 22 June 2021

(c) The Author(s) 2021

\section{Correction to: Semigroup Forum (2020) 101:534-546 https://doi.org/10.1007/s00233-020-10118-1}

The original article has been updated. Open Access funding enabled and organized by Projekt DEAL.

Open Access This article is licensed under a Creative Commons Attribution 4.0 International License, which permits use, sharing, adaptation, distribution and reproduction in any medium or format, as long as you give appropriate credit to the original author(s) and the source, provide a link to the Creative Commons licence, and indicate if changes were made. The images or other third party material in this article are included in the article's Creative Commons licence, unless indicated otherwise in a credit line to the material. If material is not included in the article's Creative Commons licence and your intended

The original article can be found online at https://doi.org/10.1007/s00233-020-10118-1.

\author{
Bernd Billhardt \\ billhardt@uni-kassel.de \\ Boorapa Singha \\ boorapas@yahoo.com \\ Worachead Sommanee \\ worachead_som@cmru.ac.th \\ Paweena Thamkaew \\ paweena_tha@ac.th \\ Jukrapong Tiammee \\ jukrapong_tia@cmru.ac.th
}

1 Fachbereich 10 - Mathematik Und Naturwissenschaften, Institut Für Mathematik, Universität Kassel, Untere Königsstraße 86, 34109 Kassel, Germany

2 Department of Mathematics and Statistics, Faculty of Science and Technology, Chiang Mai Rajabhat University, Chiang Mai 50300, Thailand 
use is not permitted by statutory regulation or exceeds the permitted use, you will need to obtain permission directly from the copyright holder. To view a copy of this licence, visit http://creativecommons.org/ licenses/by/4.0/.

Publisher's Note Springer Nature remains neutral with regard to jurisdictional claims in published maps and institutional affiliations. 